\title{
Watersheds and Trees Fall Together: An Analysis of Intact Forested Watersheds in Southern Patagonia $\left(41-56^{\circ} \mathrm{S}\right)$
}

\author{
Anna Astorga *, Paulo C. Moreno ${ }^{(D)}$ and Brian Reid \\ Centro de Investigación en Ecosistemas de la Patagonia, Coyhaique 5951601, Chile; \\ paulo.moreno@ciep.cl (P.C.M.); brian.reid@ciep.cl (B.R.) \\ * Correspondence: aastorga78@gmail.com; Tel.: +56-9-5658-6292
}

Received: 1 May 2018; Accepted: 19 June 2018; Published: 28 June 2018

\begin{abstract}
While intact forests have intrinsic value in terms of conserving biodiversity, they are also important for associated ecosystem services of soil and water conservation, in addition to the biodiversity, function and geomorphology of stream and river ecosystems. In this latter context, the perspective of watershed is more relevant than forest patch, however we are unaware of any landscape assessments of intact forested watersheds (IFWs). We mapped the coverage of forested watersheds with limited intervention for southern Patagonia (Chile, Argentina) using existing forest stand mapping and high resolution stream/watershed delineation (patch size $\sim 0.4 \mathrm{~km}^{2}$ ). Validation and adjusted IFW boundaries was performed using high resolution satellite imagery for three major inland basins representing the north-south range of the study area. For both scales we evaluated size distribution, conservation status, forest type (deciduous vs. evergreen temperate forest) and bio-climatic zones (precipitation range 500 to $>6000 \mathrm{~mm} /$ year). For the coarse regional analysis potential IFWs covered over $40 \%$ of land surface, and included nearly $60 \%$ of all forest cover. These figures were significantly reduced following basin scale validation to $6-21 \%$ for IFWs and $5-14 \%$ of forest contribution to IFW. IFWs identified in the regional analysis were lower elevation $(0-100 \mathrm{~m})$ due to abundant coastal drainages, whereas the basin analyses were higher elevation headwaters systems $(1000+\mathrm{m})$, the largest over $80 \mathrm{~km}^{2}$. Total IFW cover was estimated between $50,000-132,000 \mathrm{~km}^{2}$, the range a reflection of disparate results across these two scales, further highlighting the need for comprehensive revision and field validation. At the same time the difference in areas, defined mostly by minor levels of intervention, indicate the vast potential for management or restoration. Taken together they represent a nationally and globally significant contribution to of intact temperate forests and IFWs. Interactions between forest and stream ecosystems, and their implications for IFW conservation, are discussed in these contexts, based on examples from the region. Finally we used Getis-Ord Gi* statistics to identify hot and cold spots for different attributes, providing an example of a combined index for prioritizing IFW conservation.
\end{abstract}

Keywords: intact watershed; temperate forests; Patagonia; headwater streams; old growth forests; conservation

\section{Introduction}

Forests with limited human intervention, whether "pristine", ancient or old growth, are a limited and diminishing feature of modern landscapes [1,2]. They are essential in terms of conserving biodiversity, climate change mitigation, or as reference systems for forest management or restoration [3]. Global inventories and mapping efforts focused on forest integrity have proliferated given the concerns on the rapid decline of primary forests $[4,5]$. These efforts include global distribution analyses of 
intact forest landscapes by biome [5], estimated rate of change of forest cover [4], levels of forest fragmentation [6], global human footprint [7,8], and areas prioritized for potential restauration [9]. Intact forests are also important for associated ecosystem services of carbon storage [10], soil and water conservation, regulating hydrological regimes, and affect the structure, function, biodiversity and geomorphology of stream and river ecosystems [11-13].

Forest conservation efforts have advanced on the basis of forest patches as the basic conservation unit, usually in terms of their respective size and connectivity. However, in the broader context of forests associated with streams and catchments, the perspective of watershed seems more relevant than forest patch. Nevertheless, we are unaware of any landscape assessments of intact forested watersheds. How much do intact forests contribute to watershed conservation? Are there corresponding intact watersheds, and under what conditions? Conceivably this would go beyond forests as patches located here and there relative to the stream and watershed ecosystem, demanding a restrictive set of conditions: an undisturbed forest ecosystem conforming to the watershed boundary until some downstream point, with no gaps in coverage along the stream drainage network (with exceptions due to natural disturbance patches caused by stream or hillslope dynamics). Given these general criteria as a starting point, intact forested watersheds are likely a much more restricted subset of intact forests, in terms of both distribution and size. Presuming that intact forested watersheds are correspondingly scarce globally, and the probability of their being linked to headwaters (by definition, as watersheds are organized in linear and hierarchical networks, starting upstream), these two elements alone underscore their potentially tremendous value for freshwater conservation [14,15].

Forests intactness regulates linkages between terrestrial and aquatic ecosystems at several levels. Riparian old growth forests will be more heterogeneous in terms of light, exhibit greater volumes of large woody debris which will in turn influence the geomorphology, nutrient accumulation, habitat heterogeneity of a stream channel and aquatic biodiversity [16,17]. At regional, watershed and local scales, forests probably play a very important role in water balance [18], via processes such as evapotranspiration, snow hydrology, regulating soil development and corresponding soil hydraulic properties. All of these physical properties will vary according to the intactness of the forest, soils, and hydrologic connections within the watershed [11]. Based on these linkages, we propose the concept of intact forested watersheds (IFWs), or primary forests bounded by correspondingly intact watersheds.

Southern South America has the largest extensions of intact temperate forests in the southern hemisphere $[19,20]$. They occur along a narrow but latitudinally extensive area, from approximately 34 to $55^{\circ} \mathrm{S}$. Biogeographically, these southern South American temperate forests are likewise unique in terms of their isolation and climate [21]. An island surrounded by desert in the north and east, and ocean in the south and west, these forests are the reservoir of temperate forest biodiversity in South America [22]. A strong climatic gradient driven by prevailing westerlies (from $<300 \mathrm{~mm} /$ year precipitation in the east to $>6000 \mathrm{~mm}$ /year in the west), combined with a complex topography of the coastal mountain range and the Andes cordillera, result in area where temperate evergreen, deciduous and mixed broadleaf forests coexist in a relatively small geographic area (east-west distance of forested landscapes is $200-300 \mathrm{~km}$ ). This bioclimatic and forest diversity, together with the cleanest air-shed on earth given the very low atmospheric deposition rates [23], may be a unique world reference for watershed processes and stream ecosystems.

The overall objective of our work is to present a landscape conservation perspective using IFWs as a conservation unit, based on an ongoing mapping effort for the Southern Patagonian Region (41-56 $\mathrm{S})$. Small watersheds are a logical unit of land use planning, conservation planning and assessment of combined array of ecosystem services of soil and water conservation.

Specifically, we mapped the extent of potential intact forested watersheds with limited intervention for southern Patagonia (Chile, Argentina) using existing forest stand mapping and a new high resolution regional stream/watershed delineation (patch size $0.4 \mathrm{~km}^{2}$ ). Validation and adjustment of IFW boundaries was performed for three major inland basins using high resolution satellite imagery. For both regional and basin scales we evaluated size distribution, elevation, conservation status 
and representation of forest type (temperate deciduous and evergreen temperate rain forest) and bio-climatic zones. We present examples of integrating intact watershed and intact forest conservation using Getis-Ord Gi* statistic [24], including an example of a combined index for prioritizing IFW conservation or management [25-27]. Finally we discuss some of the challenges in defining and understanding connections between intact forests, streams and watersheds at relevant scales.

\section{Methods}

\subsection{Study Area}

We define the study area of Southern Patagonian watersheds as starting with the Río Petrohué basin (discharge at $41.5^{\circ} \mathrm{S}$, Los Lagos Region), westward to the island of Chiloé, southward to Cabo de Hornos $\left(55.91^{\circ} \mathrm{S}\right)$, and eastward to the Atlantic basins of R. Chubut (north) and Río Grande of Tierra del Fuego (Figure 1). The area includes the political jurisdictions of Los Lagos Region (Palena Province and Chiloé), Aysén and Magallanes Regions in Chile, and the Provinces of Chubut, Santa Cruz and Tierra del Fuego in Argentina. This region is characterized by lower stature southern Andes (compared to northern Andes, e.g., sea level to $3910 \mathrm{~m}$ at monte San Valentin). Lacking a prominent central valley, linear distances and/or fluvial courses from source to the sea are relatively short, and overall stream gradients relatively high. Also noteworthy are the world's largest temperate ice fields (Campo de Hielo Norte, Campo de Hielo Sur and Cordillera Darwin) and major mid-catchment lakes (second largest lake on the continent and among the deepest in the world). Trans-Andean catchments are an important feature of southern Patagonia rivers, with westward drainage of rivers Puelo, Yelcho, Palena, Aysén, Baker, while drainage of Río Grande in Tierra del Fuego is eastward, through Argentina, discharging in the Atlantic Ocean. In a region dominated by extensive fiords and islands, smaller coastal rivers also abound (approximately $60 \%$ of Chilean area in Figure 1), with significant runoff contribution despite their small size. A main characteristic of the region is the enormous climatic gradient over a short distance, with hyper-humid coastal systems affected by extreme annual precipitation ( $>6000 \mathrm{~mm} /$ year) ranging to cold steppe systems ( $<250 \mathrm{~mm}$ /year). Hydrographs of Patagonian rivers vary with origin, ranging from cold steppe (September to October peak flows), cordilleran snowmelt (November or December peak flows), glacial meltwater streams (January to February peak flows), to coastal rainforest systems (no consistent hydrograph, with frequent peaks or pulses any time of year). Although these climatic and hydrographic patterns alone are generally not distinctive at least at the global scale, the occurrence of this range of river dynamics and hydrographic features within close geographic proximity is perhaps emblematic of Patagonian Rivers.

The mapping was divided into three stages: (1) delineation of major basins and nested micro-watersheds at the regional scale; (2) overlay of watersheds with mature forest (potential primary forest) from regional forest stand inventories, to produce regional map of potential intact forest watersheds (pIFWs); (3) validation of intact forest status for three major continental basins, based on high resolution satellite imagery, followed by editing of (IFW) boundaries (Figures 2 and 3). 


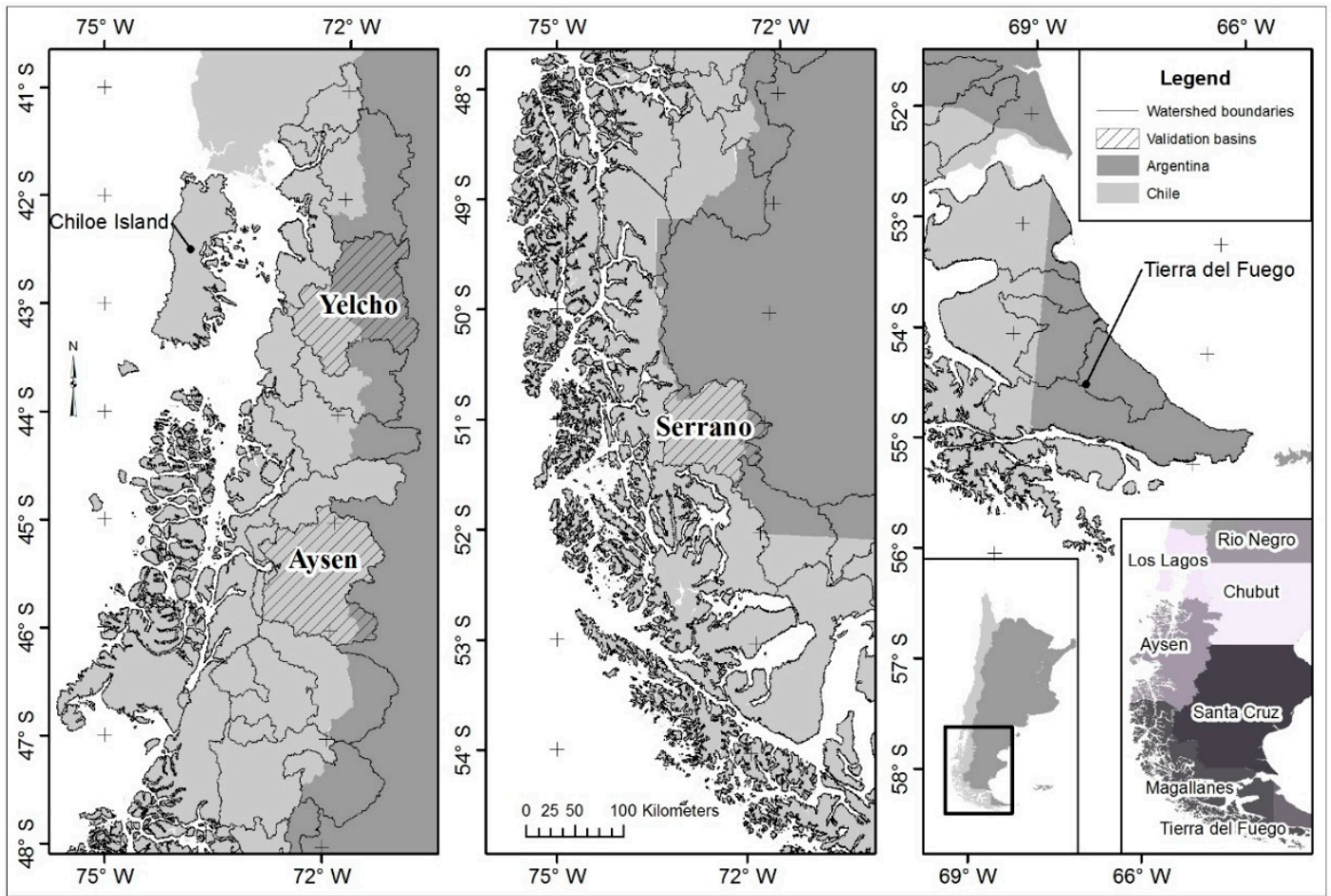

Figure 1. Mapping extent for intact forested watersheds (IFW) in Southern Patagonia. The regional mapping of potential IFW was based on mature forest cover extracted from detailed forest stand mapping (available only for the Chilean side of binational and trans-Andean basins, Table 1), from 41 to $56^{\circ} \mathrm{S}$. Validation using high resolution satellite imagery was done for three major binational basins: Río Yelcho, Río Aysén and Río Serrano. Also indicated are boundaries for all major watersheds, and political jurisdictions (inset right).

Table 1. Attributes for regional mapping area (Chile) and the three validation basins.

\begin{tabular}{|c|c|c|c|c|}
\hline General Characteristics & Region & R. Yelcho & R. Aysén & R. Serrano \\
\hline Latitude range $\left({ }^{\circ} \mathrm{S}\right)$ & $40.73-55.91$ & $42.29-43.64$ & $44.8-46.14$ & $50.59-51.60$ \\
\hline Total study area $\left(\mathrm{km}^{2}\right)$ & 317,340 & 11,331 & 12,296 & 7858 \\
\hline Precipitation range (mm/year) ${ }^{1}$ & $136-6829$ & 241-1885 & $394-2437$ & $227-1647$ \\
\hline Mean annual temperature $\left({ }^{\circ} \mathrm{C}\right)^{1}$ & $-10.3-12.2$ & $0.0-11.2$ & $-0.1-9.5$ & $-4.9-7.6$ \\
\hline Elevation range (m.a.s.l.) ${ }^{2}$ & 0-3985 & $0-2534$ & $0-2252$ & $0-2680$ \\
\hline Forest cover $\left(\mathrm{km}^{2}\right)^{3,4}$ & 129,618 & 6202 & 5538 & 1303 \\
\hline Land conversion $\left(\mathrm{km}^{2}\right)^{3,4}$ & 5241 & 120 & 1308 & 263 \\
\hline Population density $\left(\mathrm{km}^{-2}\right)^{5}$ & 1.9 & 4.1 & 6.7 & 0.2 \\
\hline
\end{tabular}

1 WorldClim downscaled bioclimatic variables [28]; ${ }^{2}$ CGIAR-CSI SRTM $90 \mathrm{~m}$ Database ver 4.1 digital elevation model [29]; ${ }^{3}$ Chile forest cover estimate based on all mapped successional forest stages. Land conversion consists of areas mapped as urban or agricultural land use within the general boundary of forested zones. Source: National Land Use inventory [30]; ${ }^{4}$ Source: Land use cover for Argentina [31]; ${ }^{5}$ Approximate population density based on Instituto Nacional de Estadística (Chile) [32] and estimated population from cities and villages (Argentina). 


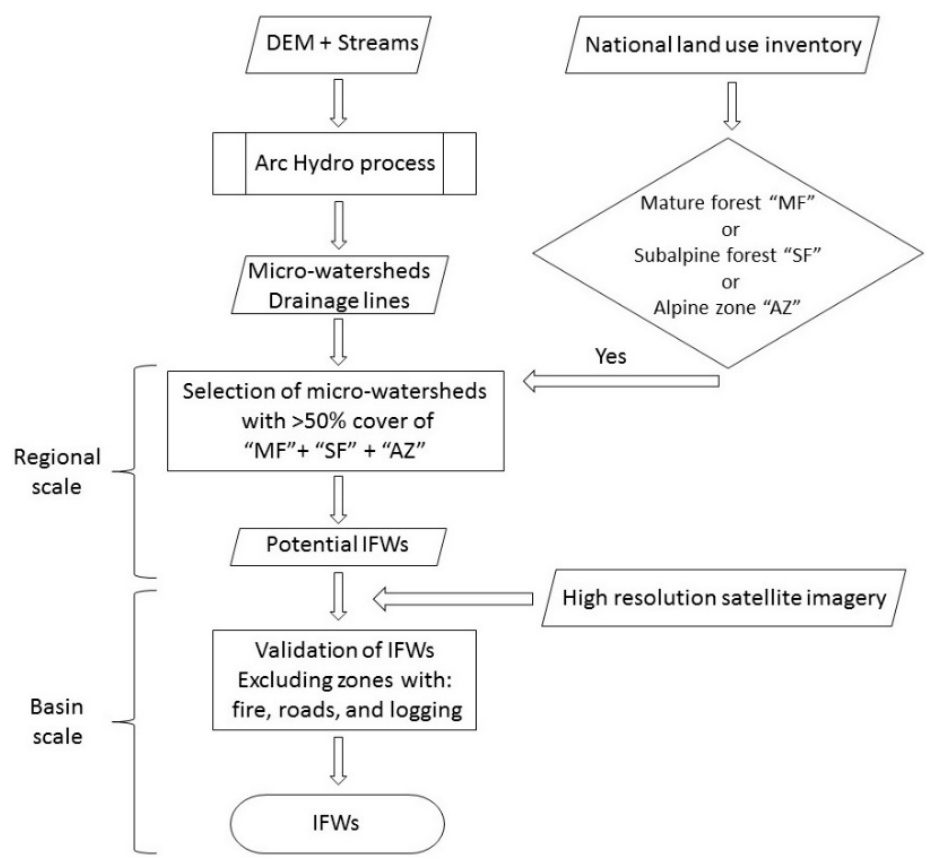

Figure 2. Diagram showing the mapping stages at the regional and basin scale. DEM: Digital elevation model.
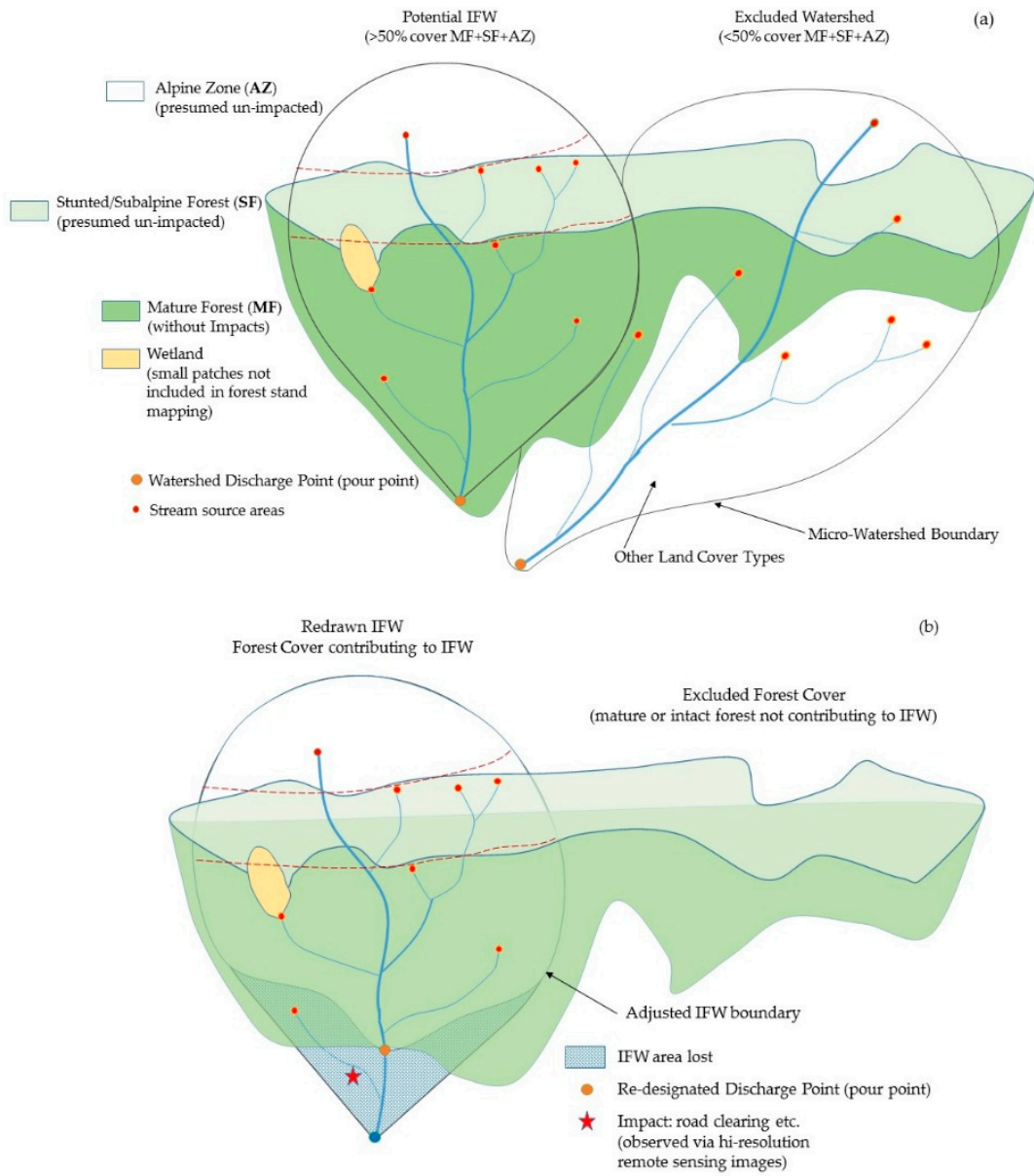

Figure 3. Mapping and decision criteria for Intact Forested Watersheds: (a) IFW designation and forest contribution for regional analysis; (b) IFW adjustment following basin scale analysis. 


\subsection{Watershed Delineation}

We defined micro-watersheds as the unit of our analysis of IFW (50 pixel minimum definition, on average $0.4 \mathrm{~km}^{2}$, but variable depending on local topography). The size threshold was based on several assumptions: this scale was consistent with the resolution of forest stand mapping (minimum patch size $\sim 0.005 \mathrm{~km}^{2}$ according to CONAF [33,34], but effectively much closer to the $0.4 \mathrm{~km}^{2}$ micro-watershed size), and the size is also consistent with minimum surface area for stream generation for much of the region (mapped "quebradas" in the surface hydrography data set). Surface hydrology and micro-watersheds were modeled for the entire study area using Arc Hydro 10.2 for ArcGIS [35], based on SRTM 90 m digital elevation model (CGIAR-CSI version 4.1 [29]), modified by "burning" the local river and stream drainage network (Surface hydrography dataset, digitized from 1970s series topographic maps, Dirección General de Aguas). The latter required previous manual editing of errors such as disconnected or missing drainage lines, especially in the Los Lagos and Magallanes region. Major basins (Figure 1), identified based on previous hydrologic balance efforts in Chile [36] were redrawn using the same procedures based on discharge point to coastal marine waters.

\subsection{Forest Mapping, Processing and Overlay with Watersheds at the Regional Scale}

We used the Chilean national land use inventory maps (NLUI [30,33,34]) as a basis for identifying forest stand types most likely associated with primary or old growth forest conditions. The regional mapping was limited to the Chilean side: comparatively detailed forest stand inventories were not available for Argentina. Based on aerial photography mosaics [33], the maps include detailed assessment of forest structure and species composition, however with some inconsistencies across regions in terms of methods, quality and year of mapping (conducted in 2013, 2011 and 2005 for the Los Lagos, Aysén, and Magallanes Regions respectively). We assumed that potential old growth forest with limited intervention would be reflected in the mature forest category (selected from three classes: open, semi-open and closed canopy) and also based on stunted "achaparrado" forest occurring in subalpine zones, the latter at higher elevations and buffered by the mature forest categories. Forest cover evaluation for Argentina at the regional level was limited to general statistics (Table 1) based on vegetation cover classes [31]. Since many of the cordilleran watersheds originate in alpine zones, the selected mature forest areas were combined with several land cover types also presumed to represent areas with limited intervention at higher elevations (rocks, ice, snow, alpine vegetation etc. (Figure 3a).

The combined area of presumed limited intervention was then overlaid with the micro-watersheds, and the results were classified based on the percentage of overlap: $50-67 \%, 67-83 \%$, and $83-100 \%$ (Figures 2 and 3a). Since the modeling of micro-watersheds was arbitrary compared to the forest distribution, and since impacts from forestry and especially fires are often distinctly limited by elevation, many of the mapped watershed units had discharge points located slightly-to-somewhat below otherwise intact forest stands that follow elevation bands. Hence we retained somewhat liberal selection of pIFWs, reflected in the three categories of overlap, for the purpose of defining an upper limit to estimates of coverage, characterization, and conservation status of potential IFWs at the regional scale (Figure 3a).

For each micro-watershed we estimated the corresponding minimum elevation (elevation of watershed discharge point to downstream ecosystems), mean elevation (elevation of the forest and watershed ecosystems themselves), mean annual precipitation (WorldClim Version 2, spatially downscaled gridded climate data based on years 1970-2000 [28]), and forest type [30]. Runoff was also estimated based on gridded precipitation raster [28], and annual runoff coefficient (c). The latter was modeled on an empirical relationship based on mass balance estimates from 52 basins ranging from 40 to $55^{\circ} \mathrm{S}$ (see Figure S1 in Supplemental Material; data from Ministerio Obras Públicas [36]). Conservation status was based on Chilean Bienes Nacionales database of public reserves, parks, private conservation lands, and non-designated public "fiscal" lands with conservation status [30,37] and Argentinean National Parks inventory [38]. 


\subsection{Validation of Primary Forest and IFWs at the Basin Scale}

The third stage of mapping consisted in a detailed validation for three major transnational basins (Yelcho, Aysén and Serrano; Figure 1) using satellite images at 1:5000 scale. The three basins represent a large part of the north-south gradient across the mapping area (Table 1), constituting nearly $10 \%$ of the regional extent. Note that being inland cordilleran basins, they may also be exposed to greater land use pressure, and may not adequately represent patterns in smaller coastal basins. A combination of ESRI world imagery (various sources, $\geq 1 \mathrm{~m}$ resolution, 2013-2015), and Google Earth (SPOT, $2.5 \mathrm{~m}$ resolution, 2011 and after) was used. Each potential IFW was evaluated for human impacts such as current and historic logging, smaller cleared areas not visible in the forest inventory, roads, and fire. Wildfires are not a common natural disturbance in these southern temperate Nothofagus forests [39]. Human caused fires were frequently used for clearing land (mainly in the valley bottoms but often affecting hill slopes) during early 20th century, continuing for almost half a century, significantly transforming the landscape, and being the main anthropogenic impact in the region [40,41]. Where any of these impacts were observed within previously mapped boundaries of potential IFWs, the watershed was delineated again by manually defining a new discharge point (pour point), located just upstream of where the stream drainage intersects the affected area (see Figure 3b). Where more than one IFW occurred contiguously to another within the same drainage network, watersheds were also merged so that any IFW discharge point represents a complete undisturbed upstream network. For each validation basin we repeated the analyses performed at the regional scale (i.e., mean elevation of IFW and conservation status of IFW). We also estimated the size distribution of IFWs, based on the final size of the merged watersheds.

\subsection{Combined Metric for IFW Conservation Priorities}

We developed an example for a combined index for prioritizing IFW conservation or management, using the Aysén basin as a case study. A common conservation planning tool for site prioritization is via the identification of hotspots [42,43]. Gi* statistics has been widely used [44] to identify hotspots, such as richness and rarity [25], biodiversity [44,45], soil conservation [46], and forest loss [44]. The index consists of hot and cold spot analysis using $\mathrm{Gi}^{*}$ statistics [24], resulting in a map of IFW clusters with the highest conservation score for selected attributes. Attributes considered for IFW conservation prioritization include: (1) lower discharge elevation, (2) greater size, (3) greater forest cover in the watershed (percentage and size), (4) lesser representation within conservation areas (percentage and size), and (5) greater annual runoff. By definition, hot spots were IFW clusters with high scores for all these criteria, and vice versa for cold spots. These conservation attributes are related to four general categories: physical setting (1 and 2), forest contribution to IFW area (3), lack of conservation representation (4) and water provisioning ecosystem service (5). Each attribute was given the same weight in calculating the final average $\mathrm{Gi}^{*}$ statistic, this for illustration purposes (final assignment of weight incurs value judgements beyond the scope of this paper), The spatial relationship used for $\mathrm{Gi}^{*}$ statistic was contiguity through edges and corners to identify those IFWs groups with both high attribute values and also landscape connectivity. False discovery rate (FDR) correction was applied to avoid multiple testing problem and to incorporate the spatial dependency of observations. Significance levels of $90 \%, 95 \%$ and $99 \%$ were used for both hot and cold spot scores. Database management, vector and raster processes and statistical analyses were performed using ArcGis 10.4.1 for desktop [40] and R v. 3.2.2 statistical software [41].

\section{Results}

\subsection{Regional Analysis of Mature Forested Watersheds (Chile)_Geographic and Bioclimatic Distribution}

From a total study area of over $317,000 \mathrm{~km}^{2}$, total forest cover including all successional stages was $40.8 \%$ (Table 1). Mature forest, as an indicator of maximum potential old growth or primary forest (based on data available for Chile only) was $81.3 \%$ of total forest cover at the regional scale. Meanwhile 
$78.4 \%$ of this mature forest (or $63.7 \%$ of total forested area) contributed to intact forested watersheds in the region (following criteria in Figure 3a). The total area of potential IFWs was calculated as $134,176 \mathrm{~km}^{2}$ (Figure 4), distributed as 19,979, 22,342, and 91,856 for the respective 50-67\%, 67-83\%, and $83-100 \%$ forest cover classes. Figure 4 represents the likely maximum extent of IFWs in Southern Patagonia. Potential IFWs were mainly distributed in the central cordillera and interior coastal fiords of the Aysén region ( $\left.43-47^{\circ} \mathrm{S}\right)$, Palena province $\left(40-43^{\circ} \mathrm{S}\right)$, and western slope of the coastal range in Chiloe (Figure 4a). Larger contiguous areas of pIFWs are especially notable in the inner fiords. Following detailed revision of intact river systems consisting of pIFWs (not shown here), two 4th order rivers at approximately $45^{\circ} \mathrm{S}$ stood out $\left(\sim 280 \mathrm{~km}^{2}\right.$ and $\sim 310 \mathrm{~km}^{2}$ respectively). More fragmented distribution of IFWs of predominantly deciduous forest cover was observed southward in the Magallanes region, including western Tierra del Fuego. Very limited occurrence of pIFW was evident in the islands, canals and fiords north of the Taitao peninsula $\left(46^{\circ} \mathrm{S}\right)$ and also the southern and southwestern-most coasts (Cape Horn Biosphere Reserve).
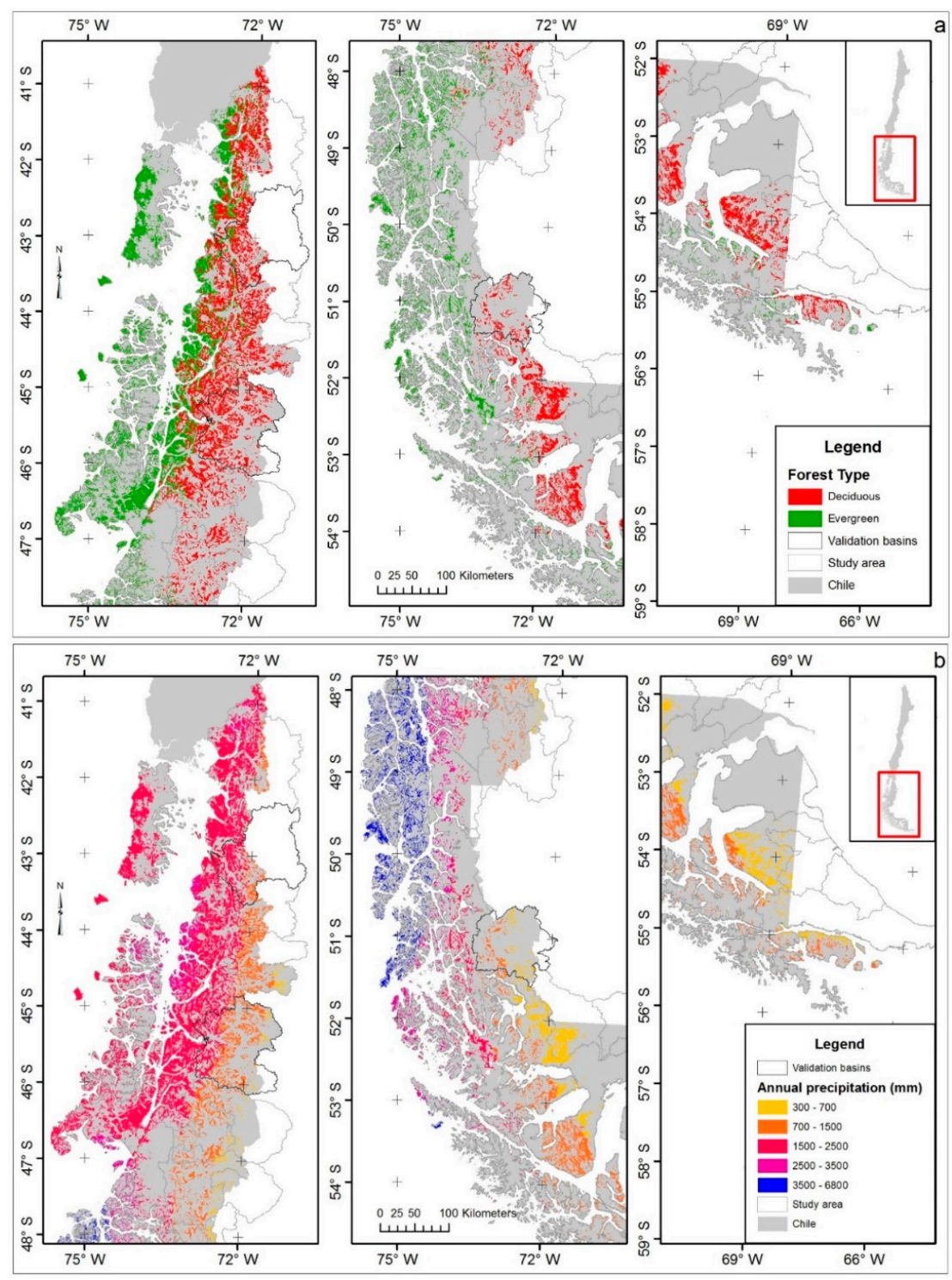

Figure 4. Regional map of potential IFWs in Chile, as a function of deciduous/evergreen phenology (a) and annual precipitation (b). Note that watersheds classified as evergreen forest type include many transitional or mixed types, often with deciduous species at higher elevations within the same watersheds (see text). 
Potential IFWs were more frequent at intermediate annual precipitation (500 to $2500 \mathrm{~mm} /$ year, Figures $4 b$ and $5 a)$, compared to the very broad climatic range in the region (200 to $7000+\mathrm{mm} /$ year), corresponding with the above mentioned spatial distribution (central cordillera and inner coast). Two distinct distributions were observed for pIFW elevation (Figure 5b). A lognormal distribution of discharge points (pour points) reflects the high frequency of small coastal watersheds. There was a more uniform distribution based on the PIFW centroid, a better indication of the mean elevation of forested area or hydrologic contributing to pIFWs (Figure 5b). Cover type was nearly equally represented by deciduous forest (Nothofagus pumilio (Poepp. \& Endl.) Krasser and Nothofagus antarctica (Forster) Oerst.) and evergreen forests (mainly Nothofagus dombeyi Mirb. Oerst., Nothofagus betuloides (Mirb.) Oerst., Nothofagus nitida (Phil.) Krasser, Drimys winteri J.R. Forst. \& G. Forst., Laureliopsis philippiana (Looser) R.Schodde, Pilgerodendron uviferum (D.Don) Florin, Tepualia stipularis), with nearly $30,000 \mathrm{~km}^{2}$ of each (Figure $5 \mathrm{c}$ ): note that the latter includes several classes of mixed evergreen and deciduous forest (not treated here). Finally, over $46 \%$ of the total forested area of potential IFWs was represented within public or private conservation areas (Figure $5 \mathrm{~d}$ ), with $67 \%$ of evergreen forests and $33 \%$ of deciduous forests within some public or private conservation category.
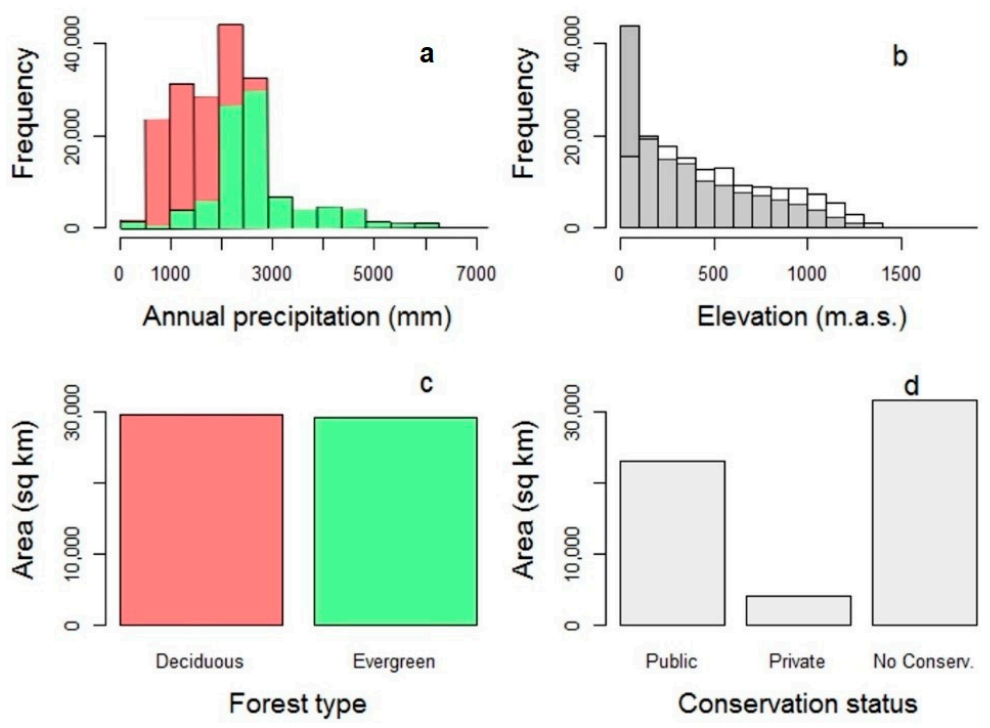

Figure 5. Elevation and bioclimatic distribution and vegetation cover of potential IFWs in the regional mapping area. Annual precipitation related to forest type ((a), stacked graph), watershed discharge elevation (grey) and mean elevation (superimposed, white) (b), forest type (c), and conservation status (d).

\subsection{Validation Sites—Revised IFW Status for Three Large Continental Basins}

Validation of IFWs via high resolution imagery for the Yelcho, Aysén and Serrano basins (Figure 6) indicate that only a small fraction of forest contributes to IFWs, compared to total forest cover and mature forest cover. For all three basins the most dramatic reduction in area of intact forest contribution to IFWs was observed at lower elevations (0-500 m, Figure 6a,c,e), generally corresponding with human occupation of valleys, exclusion of valleys from conservation areas, and presumably easier access from road networks. The Aysén basin, which has the most significant human population among the three basins, also had the greatest area of IFWs; at the same time this basin had the strongest reduction between forested area and intact forest contributions to IFWs (Figure 6c). Impacts to evergreen forest contribution to IFWs was also much greater than for deciduous forest, at least for the two basins where both forest cover types were present (Figure $6 \mathrm{~b}, \mathrm{~d}$ ).

Compared to regional scale patterns described above, the three validation basins show significant reduction in both intact forest cover and their contribution to IFWs, in addition to a general trend of increasing impacts southward along the north to south gradient. Approximately $10 \%, 14 \%$ and $6 \%$ of 
total forest cover contributed to IFWs for the Yelcho, Aysén and Serrano basins respectively, compared to the $67 \%$ estimated via the first iteration and coarse regional scale. Corresponding IFW areas were $20 \%, 21 \%$ and $6 \%$ of total basin area respectively (Figure 7). Estimates of IFW area was significantly reduced following detection of unmapped roads, evidence of clearing and historic fires, and recent forestry activities. Note that although these estimates define the lower limit for IFWs in the region, again pending field validation, the degree of impacts and whatever residual conservation value, or management/restoration potential, have not yet been determined, this for a significant area at play between the regional mapping (representing upper limit) and basin scale mapping (current lower limit) of IFW estimates.

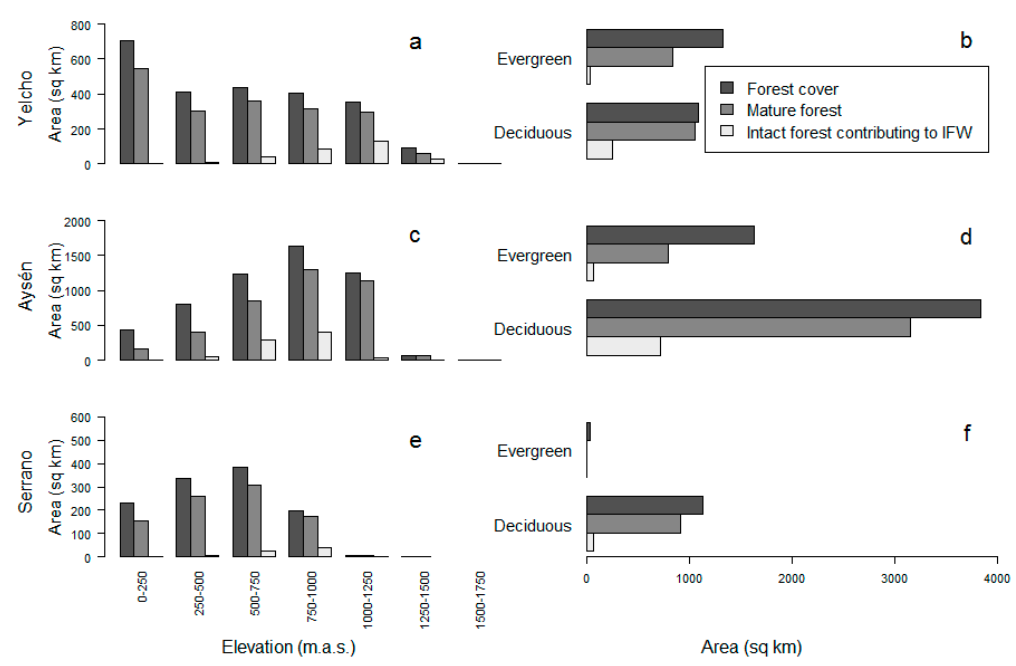

Figure 6. Comparison of total forest cover (all successional stages combined) with mature forest patches and intact forest contribution to IFWs: Yelcho river, Aysén river and Serrano river basins. Elevation distribution (a,c,e) and evergreen/deciduous forest type (b,d,f) shown respectively for the three basins. Note elevation scale adjusted for each basin.
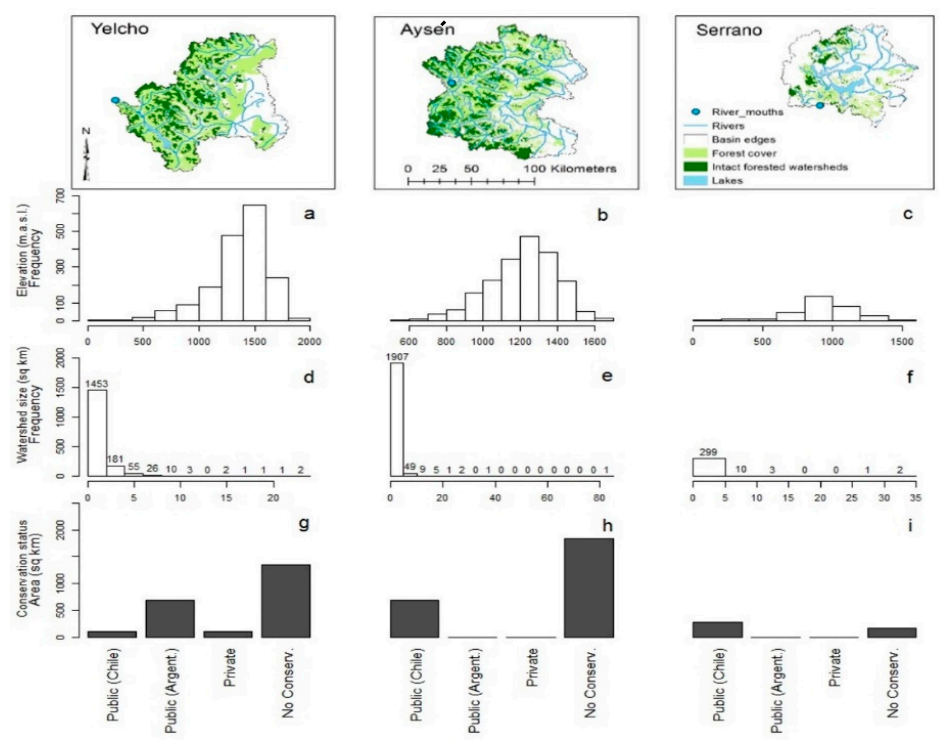

Figure 7. Attributes of intact old growth forest watersheds in the Yelcho, Aysén and Serrano validation basins. Upper maps show spatial distribution represented by light green (all forest types) and dark green (intact IFWs). Frequency distribution of intact IFWs is shown for discharge elevation (a-c), watershed area $(\mathbf{d}-\mathbf{f})$ and conservation status $(\mathbf{g}-\mathbf{i})$, with public conservation lands for the latter category partitioned between Chile and Argentina. 
IFWs for validation basins were located at mean elevations of 1500, 1250, and $900 \mathrm{~m}$ respectively (Figure 7a-c), distinctly higher elevations than the regional analysis (Figure 5), and with the distribution notably skewed towards higher elevation systems. Most of the watersheds were under $5 \mathrm{~km}^{2}$ for Yelcho and Serrano, but the Aysén basin presented a larger range in sizes, the largest IFW approximately $80 \mathrm{~km}^{2}$ (Figure 7d-f). Representation within protected areas also varied across basins, with Yelcho approaching $40 \%$ (similar to the regional average, but largely due to protected areas in Argentina), Serrano somewhat higher with approximately 62\% under conservation, while the Aysén basin was clearly lower at around $27 \%$ with conservation protection (Figure $7 \mathrm{~g}-\mathrm{i}$ ).

\subsection{Prioritizing IFW Conservation-Example of Combined Metric Approach from the Aysén Basin}

The conservation value analysis for the Aysén basin (Figure 8) showed hotspots for physical context of IFWs at lower elevations and larger size (Figure 8a,b). Conversely, conservation status indices showed no significant areas where IFW representation was wanting, but instead suggested that many of the largest IFW clusters were already within protected areas (Figure 8c,d). A more complex response was observed to the forest cover metrics, the otherwise subtle distinction between forest patch size and contribution to IFW area producing very disparate results in terms of hot/cold spots and also their geographic distribution (Figure 8e,f). The runoff analysis favored larger complexes of IFWs generally corresponding with indices for IFW size (b) and forest cover patch size (f). Finally, the combined metric, shown for example purposes only (see discussion) appears to be sensitive to all of the individual metrics except those relating to conservation status.

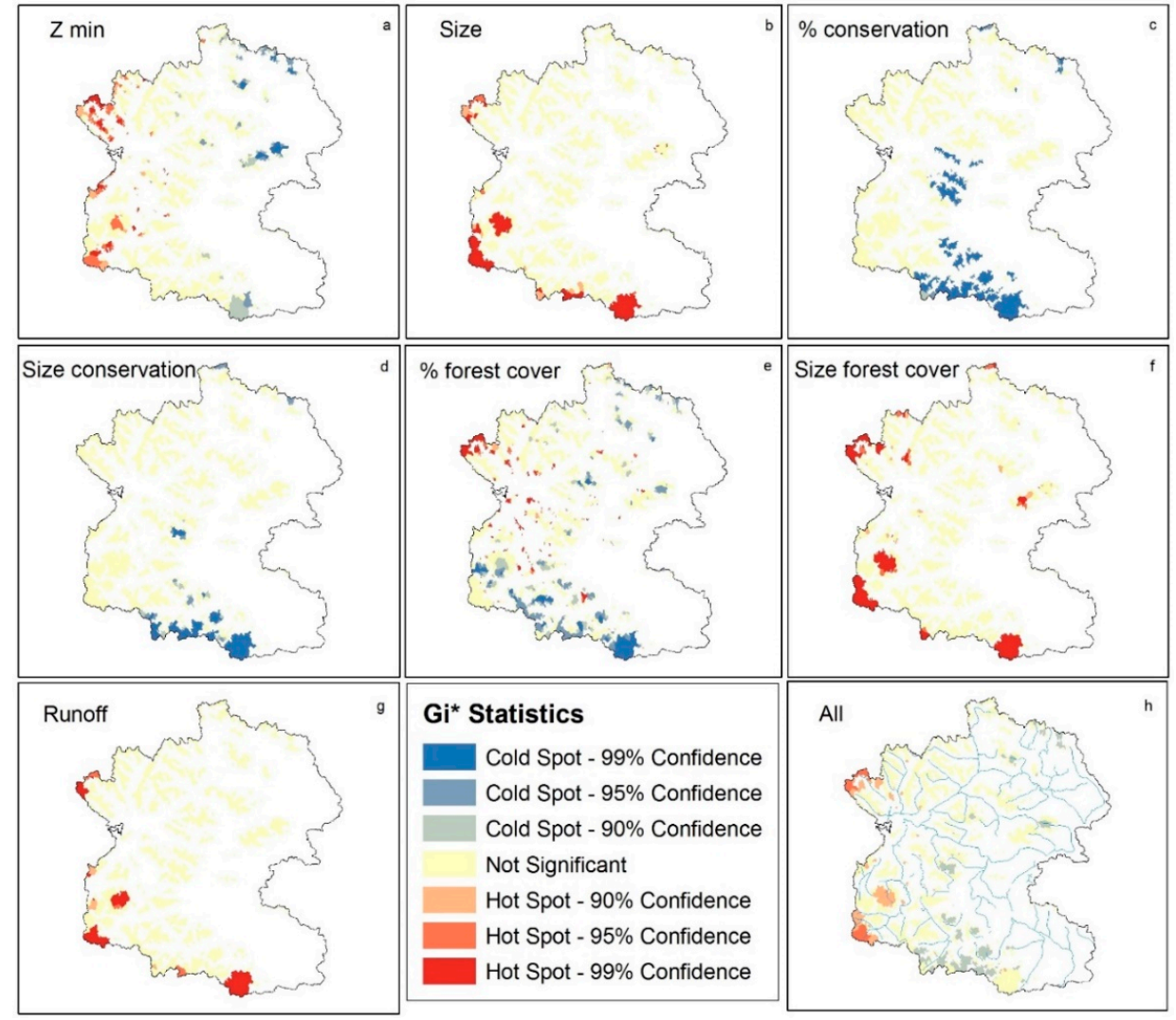

Figure 8. Example of IFW conservation assessment and prioritization for the Aysén watershed. Shown are $\mathrm{Gi}^{*}$ indices for select physical attributes (minimum elevation $\mathrm{Z}$ min, clustered size), forest attributes ( $\%$ forest cover, forest patch size), conservation status ( $\%$ conservation cover, size of conservation clusters) and hydrology (runoff). A combined $\mathrm{Gi}^{*}$ index is shown, assuming equal weight for each individual index (see text). 


\section{Discussion}

\subsection{Maximum and Minimum Estimates of IFWs in Patagonia}

The spatial distribution of potential IFWs at the regional scale (Figures 4 and 5) corresponds with a summary of observations on land use, deforestation impacts and areas of relative intactness in the region compiled nearly 50 years ago [47], especially with respect to the remote fjords and canals. The Aysén Region area has historically remained the most isolated region in Chile, with colonization and concurrent forest impacts from wildfires and agricultural development being insignificant up until the early to mid-20th century [19]. Contrary to this, there has been nearly complete intervention in the north-western islands (43-46 $\mathrm{S}$ ), fueled mostly by demand for cedar (Pilgerodendron uviferum), intentional wildfires [47], and other economic interests [48]. What intact forests remaining near these areas of heavy exploitation correspond with tree species of lesser demand in western Chiloe [47] or failed attempts at colonization of the Taitao peninsula [49]. In summary, the regional map (Figure 4) represents the maximum probable extent of IFWs in southern Chilean Patagonia, based on the assumption that mature forest classes may indicate potential intact forest patches. Regarding this assumption, the cautions mentioned by other authors [20,50] are echoed here, and highlight the need for external validation of intact forests and IFWs.

Validation for basin scale maps and analysis (Figures 6 and 7) may likewise provide an indication of the reduction in extent of IFWs using more rigorous criteria, assuming that the three basins are representative subsamples along a north-south gradient. The difference in IFW coverage between the regional analysis and the basin scale validation is striking: forest contribution to IFWs was reduced from $60 \%$ to between 6 to $14 \%$ of total forest cover respectively, while IFW area was reduced from $41 \%$ to $6-20 \%$ of the total land cover. In part the differences in per cent coverage of IFWs are due to very liberal initial assumptions of the regional analysis: the remote sensing validation permitted observations of interventions that are not reflected in the Chilean national forest stand inventory. IFW cover at the basin scale was also influenced by the inclusion of contributing basin area in Argentina, where adequate forest stand mapping was lacking, and whose land use history may be different from the Chilean side (including colonization history, demand for wood products at the edge of the cold steppe biome, legal designation and management of conservation areas, among others).

Variation in the amount and character of intact forest cover and IFWs was also evident across the three validation basins. Some aspects of this variation make sense from a geographic perspective, such as the trend of reduced elevation from north to south (Figure $7 \mathrm{a}-\mathrm{c}$ ), which in part follows southward reductions in tree line. Other patterns are contrary to expectations: the basin with the highest proportion of IFWs (Aysén) also had the highest human population density (Table 1). Here the trend across the three basins is perhaps more related to differences in time since colonization within Patagonia, the interior of the Aysén region (which characterizes the Aysén basin) being the most isolated and most recently accessed by explorers and colonists. Finally, differences in protected area status of IFWs across the three validation basins (Figure 7i) correspond with neither the latitudinal gradients nor local demography, and are more arbitrary or geopolitical in nature. Designation of conservation areas is often determined by values other than forest or watershed integrity, in practice river valleys and other moderately productive albeit sparsely populated areas frequently excluded. Finally differences in park designation and also management between Chile and Argentina may drive the patterns in Figure 7, with one of the more significant National Parks included on the Argentina side of the Yelcho Basin, at the same time offset by a more permissive stance in Argentina regarding hydropower development within national park boundaries.

Regardless, for both regional and basin scales the general conclusion is that only a subset of previously mapped mature forest patches are without evidence of intervention, and only a fraction of the areal extent of those intact forest patches contribute to IFWs (i.e., Figure 3). IFWs should therefore be more scarce than, and more threatened than, intact forest (or primary, ancient, old-growth, however defined). Secondly, given the disparate response across the three validation basins, any estimate of 
intact forest or IFW coverage basin on scaling from these three basins will likely produce large errors and uncertainties. It is clear that comprehensive validation via high resolution imagery and field validation is necessary for the entire region. No one basin or geographic area is representative of the Patagonia region, with its diversity in geography, climate and land use pressures. Thirdly, the area in question, over $120,000 \mathrm{~km}^{2}$ for the regional analysis of pIFWs, or in the range of $50,000 \mathrm{~km}^{2}$ for IFWs (15.6\% of the total study area, based on the average for the three validation basins), is by either estimate a significant area. In summary, presented here is a first estimate of intact forested watersheds in southern Patagonia. Like the iterative national land use and forest mapping it is largely based on, it represents a state of knowledge rather than an absolute.

\section{2. $\mathrm{pIFW}$ vs. IFW: Conservation Value and Management within the Intermediate Zone}

For conservation purposes, the areas identified using the regional approach (maximum estimate of pIFWs) and subsequently discarded based on the methods for corresponding validation basins (approaching the minimum coverage, or validated IFWs), may indeed still have some significant conservation value. This depends upon assumptions of what constitutes "intact," which may differ between the perspective of the forest (e.g., see http:/ / www.intactforests.org/concept.html [51] or the stream such as IHA or the indicators of hydrologic alteration [52]). This is also subject to practical limitations upon what may or may not be visible through remote sensing, basic field observations, or more intensive ecological studies (in order of decreasing practical applicability over large scales).

Untangling this relationship requires an ecosystem perspective on forest versus watershed patches, which is treated only briefly, below. Lacking any better criteria, intervention to the coupled forest-stream ecosystem is defined here as irreversible alteration to soils and parent material, that might affect hydrology, biogeochemistry and forest productivity/structure over short to medium time scales (10 s to $\sim 100+$ years, or scales equivalent to the expected global change stressors). For example, some of the readily visible signs of intervention, such as evidence of animal transit or occupation between grazing areas, disperse effects of historic selective logging or high-grading (usually using animal power rather than heavy machinery), associated temporary roads, and possibly even low intensity ground fires at the margins of historic wildfires, all may have limited observable long-term impacts on either the forest or stream ecosystem. The previously mentioned impacts all have potential for short-term recovery, this more or less in the order given. More irreversible effects might be expected with biochar residue from more intense wildfires (Wildfire is not considered a dominant natural process in Chilean Patagonian forests, although it does affect forests to some degree on the Argentinean north-eastern part of the study region [19]). Any processes reducing soil stability or contributing to erosion of soils and stream banks, including more intense historic wildfires, firewood cutting (currently in a phase of significant expansion) and associated road networks, might also be irreversible given the dominant Andosol soil series (e.g., Dörner et al. [53]). Perhaps the effects of invasive ecosystem engineers such as beaver (Castor canadensis) may be considered long term and mostly irreversible (but note perspective of Anderson et al. [54]), restoration potential being contingent upon eradication.

The difference between the results of the regional vs. basin scale mapping is an indication of a still great degree of uncertainty of the extent of what should be defined as IFWs. It is at the same time probably a critical area for management in terms of IFW buffers or gradients of restoration potential (considering the three categories of pIFW). However this requires an added level of assessment beyond the current scope of this work, and only general examples or guidelines are provided in the following two sections.

\subsection{Valuation of IFWs as a Trade off among Conservation Objectives}

The example shown here (Figure 5) of how various metrics for IFWs might be combined, do not, it should be noted, reflect current conservation priorities, but are an illustration of how conservation priorities might have to be balanced if a watershed perspective was included in the mix. A more sophisticated analysis could be performed for any the individual conservation indices suggested here. 
Our example is simplified out of necessity of developing a starting point for regional analysis, given the vast array of forest community types [55], extreme climatic range, and topographic complexity of southern Patagonia. For example, one might ask where the intact examples of reference forest communities are, or priorities identified via existing aquatic classification systems or basin scale conservation plans (i.e., Peredo-Parada et al. [56]; Universidad de Chile [57]; Urciuolo et al. [58]) intersect with IFWs? One response to the latter question is that the overlap in values is very limited, since IFWs are clustered in the headwaters (i.e., Figure 8), biodiversity of IFWs is virtually unknown, meanwhile existing classifications schemes are reach-based and often oriented towards conserving endemic fauna in the region (e.g., Abell et al. [59]).

Ultimately, the final $\mathrm{Gi}^{*}$ index presented here (Figure 8 ) is not an absolute but really a tradeoff between ways of valuing the landscape. In other words, borrowing from the ecosystem services approach (sensu MEA [60]), how might the various ecosystem services intersect with IFWs? One might imagine that any use of IFWs as conservation units might ultimately seek to balance values of forest conservation, forest productivity, carbon sequestration, water storage and water yield downstream (e.g., Donoso et al. [61]). As mentioned below, the forest and stream ecosystems are linked, but also present very different scales and degrees of response to any given external forcing. We make no pretense that there is any happy convergence between any or all ecosystem service values, and more likely some or all conflict with or offset one another, to some degree.

\subsection{Implications for Landscape Conservation}

Given that old growth forests have long been a focal point for regional conservation [51], and that watershed management has not been without likewise level of attention: where might the combined concept of IFWs be used, both in the Patagonian region and on a global scale? We are not aware of examples where these two approaches have been approached simultaneously in any meaningful way (for one possible exception see the Northwest Forest Plan Aquatic Conservation Strategy [62]). The importance of headwater streams $[15,63]$ is certainly the natural starting point, but where does it start, and how far downstream can it be taken? The answer depends in part on local geography (stream origin relative to tree line elevation), and the finer scale nature of interactions between forest and stream ecosystems, and watershed processes above and below this line.

General guidelines on the management or conservation of streams originating below the forest line and for respective reaches below the zone of IFWs include the protection of riparian buffers or the consideration of hydrologically active zones, especially in the management of private or public concession lands (Figure $7 \mathrm{~g}-\mathrm{i}$ ). Continuous vegetated buffers without interruption, however determined in width [64], are critical for soil stability, controlling erosion, regulating sediment supply to streams and local channel morphology. Forest canopy buffers are important from the perspective of shading and light environment [65], and forest structure (i.e., that structure characteristic of intact forests) regulates stream habitat structure via stream woody debris [16]. Beyond buffers, an expanded area of hydrologically active zones [66] provides a more refined approach to looking at prioritizing land use/stream interactions compared to commonly used bulk percentages of land use cover. On a more technical level, the direct link between forest and stream ecosystems is perhaps no better illustrated that the phenomenon of diel cycles in stream discharge [67] temperature, and biogeochemistry [68]. Monitoring of diel trends (i.e., via high frequency sensor networks) might lead to indices for the strength of the forest stream interaction.

Equally important in the conservation planning of IFWs is the consideration of where on the landscape the links between forest and stream ecosystems might diverge. Streams in the southern Andes cordillera often originate in the alpine zone, with a proportion of runoff contributed by forested hillslopes (the stream network integrating across this boundary). Both ecosystem function and conservation values of IFWs may therefore differ depending on the location of this boundary. Within the regional study area, tree line ranges from around $1600 \mathrm{~m}$ in the north, $1200 \mathrm{~m}$ in Aysén (Alex Fajardo, pers. com.) and around $600 \mathrm{~m}$ at the southernmost islands of Tierra del Fuego [69]. 
Much of the cordilleran watersheds exceed this elevation, while those in the coastal ranges (Chiloé), and coastal islands and fiords are below it. Streams ecosystems that originate within the forest limit may be more directly linked to forest ecosystems. In this situation the value of IFWs may be greater to downstream ecosystems and services, while the conservation of intermediate areas subject to guidelines mentioned above (intact forested buffers, hydrologically active zones etc.).

Streams that originate above the tree line may be less affected by forest ecosystems even in downstream reaches, as a function of contributing watershed area above and below tree line. Illustration of this divergence might be made by way of how forest and stream ecosystems would respond forcing such as intense precipitation events. Such events may have limited visible effects on the forest (beyond soil or groundwater recharge). However profound effects may be manifest upon the stream ecosystem, by way of erosion, channel alteration and significant pulses of sediment downstream, this especially where alpine streams originate from areas with steeper slopes. Characterization of stream origin and the representation of stream slope across the landscape remains a future objective of IFW characterization in the region, as does any on the ground observations of where thresholds for forest-stream ecosystem divergence occurs.

The inverse way of looking at this divergence between forest and stream ecosystem lies with the concept of vegetation succession. It is among the oldest and most widely useful concepts in terrestrial ecology, although by no means without disagreement (as useful concepts often are). It is noted, however, that the concept has not been applied in any significant way to aquatic ecosystems, (possibly the only example being Fisher et al. [70]). If a mature forest can approach an advanced ecosystem state, why wouldn't also the corresponding stream ecosystem, with its origin generated within that same forest? Space for time substitution might be one approach to this question, one that might be particularly well suited to Patagonian ecosystems, with vast areas subject to a range in patterns of glacial retreat. The discussion of disturbance and succession, on the other hand, may be as problematic in the case of "intact" forested watersheds as it is for climax vegetation communities. In general, forests and streams are effectively linked ecosystems, with some common drivers, but position on the landscape may drive very different response (in terms of resistance, resilience, and time scales) to external forcing and disturbance.

In a region where the argument is often publicly voiced that nearly $50 \%$ coverage of protected areas is good enough or even excessive, a necessary rebuttal may require the evaluation of IFW patterns in the landscape from strong social perspective. The proportion of IFWs and pIFWs contributing to potable water supplies, especially for urban areas, might be highlighted in terms of conservation protection or general forest management. IFWs in the headwaters may contribute to high water transparency and ultra-oligotrophic conditions in some Patagonian lakes. Since many other factors such as local land use, relative catchment size and water residence time are also certainly factors here, criteria are needing for weighing the relative importance of IFWs in downstream ecosystems, up to and including coastal discharge affecting marine ecosystems.

\section{Conclusions}

In summary, presented here is a first estimate of intact forested watersheds in southern Patagonia. Like the iterative national land use and forest mapping it is largely based on, it represents a state of knowledge rather than an absolute. Over $130,000 \mathrm{~km}^{2}$ of pIFWs were mapped, or $41 \%$ of Chilean Patagonia, based on the regional analysis and less rigorous mature forest criteria. That estimate is reduced to around $50,000 \mathrm{~km}^{2}$ for IFWs based on remote sensing observations from three validation basins, although variation in physical setting, conservation status, and size distribution across the three basins highlight the need for comprehensive validation across the entire study area. Both Figures, as maximum and minimum estimates of IFW coverage, represent an area of global significance. However only a subset of mapped mature forest patches were without evidence of intervention, and perhaps more importantly only a fraction of the areal extent of intact forest patches contributed to IFWs. The difference between the results of the regional vs. basin scale mapping is an indication of the 
degree of uncertainty of the extent of what should be defined as IFWs. It is at the same time probably a critical area for management in terms of IFW buffers or gradients of restoration potential.

Presented is an example of hot spot analysis $\left(\mathrm{Gi}^{*}\right)$ as a potential conservation evaluation tool, balancing conservation status, forest patch, and water yield (among other possibilities). Also discussed are relevant forest and stream ecosystem concepts, how they may be related to conservation evaluation above and below tree line, and the need for criteria and studies for weighing the relative importance of IFWs in downstream ecosystems.

Supplementary Materials: The following are available online at http:/ /www.mdpi.com/1999-4907/9/7/385/s1, Figure S1: Relationship between mean basin precipitation and annual unoff coefficient for 52 stations I southern Chile. Observed stations (symbols) correspond to a Monod function (line) with $\mathrm{Kmax}=1$ and $\mathrm{Ks}=500 \mathrm{~mm} /$ year.

Author Contributions: B.R. and A.A. conceived the idea and designed the project, P.C.M. and B.R. analyzed the data and A.A., P.C.M. and B.R. wrote the paper.

Funding: J.M. Kaplan Fund grant for the project: “Conservation of ancient forests and intact watersheds in Patagonia" awarded to A.A. and B.R. This research was funded by FONDECYT grant number 11140095 awarded to A.A. A.A. was supported by project Laboratorio Ecoclimático R17A10002 awarded to CIEP and funded by CONICYT. B.R. was supported by project SAFER, CRN358, Inter-American Institute for Global Change Research.

Acknowledgments: We acknowledge the support and feedback of David Tecklin and PEW Charitable Trust on the initial elaboration of the project. We also thank Aldo Farias for sharing data. We acknowledge Jerry Mead and Roger Thomas from Patrick Center of Academy of Natural Sciences, Drexel University, for stimulating our interest in old growth forested streams.

Conflicts of Interest: The authors declare no conflict of interest.

\section{References}

1. Morales-Hidalgo, D.; Oswalt, S.N.; Somanathan, E. Status and trends in global primary forest, protected areas, and areas designated for conservation of biodiversity from the global forest resources assessment 2015. For. Ecol. Manag. 2015, 352, 68-77. [CrossRef]

2. Watson, J.E.M.; Evans, T.; Venter, O.; Williams, B.; Tulloch, A.; Stewart, C.; Thompson, I.; Ray, J.C.; Murray, K.; Salazar, A.; et al. The exceptional value of intact forest ecosystems. Nat. Ecol. Evol. 2018, 2, 599-610. [CrossRef] [PubMed]

3. Mackey, B.; DellaSala, D.A.; Kormos, C.; Lindenmayer, D.; Kumpel, N.; Zimmerman, B.; Hugh, S.; Young, V.; Foley, S.; Arsenis, K. Policy options for the world's primary forests in multilateral environmental agreements. Conserv. Lett. 2015, 8, 139-147. [CrossRef]

4. Hansen, M.C.; Potapov, P.V.; Moore, R.; Hancher, M.; Turubanova, S.; Tyukavina, A.; Thau, D.; Stehman, S.; Goetz, S.; Loveland, T. High-resolution global maps of 21st-century forest cover change. Science 2013, 342, 850-853. [CrossRef] [PubMed]

5. Potapov, P.; Hansen, M.C.; Laestadius, L.; Turubanova, S.; Yaroshenko, A.; Thies, C.; Smith, W.; Zhuravleva, I.; Komarova, A.; Minnemeyer, S. The last frontiers of wilderness: Tracking loss of intact forest landscapes from 2000 to 2013. Sci. Adv. 2017, 3, e1600821. [CrossRef] [PubMed]

6. Haddad, N.M.; Brudvig, L.A.; Clobert, J.; Davies, K.F.; Gonzalez, A.; Holt, R.D.; Lovejoy, T.E.; Sexton, J.O.; Austin, M.P.; Collins, C.D. Habitat fragmentation and its lasting impact on earth's ecosystems. Sci. Adv. 2015, 1, e1500052. [CrossRef] [PubMed]

7. Sanderson, E.W.; Jaiteh, M.; Levy, M.A.; Redford, K.H.; Wannebo, A.V.; Woolmer, G. The human footprint and the last of the wild: The human footprint is a global map of human influence on the land surface, which suggests that human beings are stewards of nature, whether we like it or not. BioScience 2002, 52, 891-904. [CrossRef]

8. Venter, O.; Sanderson, E.W.; Magrach, A.; Allan, J.R.; Beher, J.; Jones, K.R.; Possingham, H.P.; Laurance, W.F.; Wood, P.; Fekete, B.M. Global terrestrial human footprint maps for 1993 and 2009. Sci. Data 2016, 3, 160067. [CrossRef] [PubMed]

9. WRI. Atlas of Forest and Landscape Restoration Opportunities. Available online: http:/ /www.wri.org/ resources/maps/atlas-forest-and-landscape-restoration-opportunities (accessed on 13 November 2017).

10. Luyssaert, S.; Schulze, E.-D.; Börner, A.; Knohl, A.; Hessenmöller, D.; Law, B.E.; Ciais, P.; Grace, J. Old-growth forests as global carbon sinks. Nature 2008, 455, 213-215. [CrossRef] [PubMed] 
11. Vertessy, R.A.; Watson, F.G.; Sharon, K. Factors determining relations between stand age and catchment water balance in mountain ash forests. For. Ecol. Manag. 2001, 143, 13-26. [CrossRef]

12. Brookhuis, B.; Hein, L. The value of the flood control service of tropical forests: A case study for trinidad. For. Policy Econ. 2016, 62, 118-124. [CrossRef]

13. D'Odorico, P.; Laio, F.; Porporato, A.; Ridolfi, L.; Rinaldo, A.; Rodriguez-Iturbe, I. Ecohydrology of terrestrial ecosystems. BioScience 2010, 60, 898-907. [CrossRef]

14. Saunders, D.; Meeuwig, J.; Vincent, A. Freshwater protected areas: Strategies for conservation. Conserv. Biol. 2002, 16, 30-41. [CrossRef]

15. Lowe, W.H.; Likens, G.E. Moving headwater streams to the head of the class. BioScience 2005, 55, $196-197$. [CrossRef]

16. Keeton, W.S.; Kraft, C.E.; Warren, D.R. Mature and old-growth riparian forests: Structure, dynamics, and effects on adirondack stream habitats. Ecol. Appl. 2007, 17, 852-868. [CrossRef] [PubMed]

17. Warren, D.R.; Kraft, C.E.; Keeton, W.S.; Nunery, J.S.; Likens, G.E. Dynamics of wood recruitment in streams of the northeastern us. For. Ecol. Manag. 2009, 258, 804-813. [CrossRef]

18. Bond, B.J.; Meinzer, F.C.; Brooks, J.R. How trees influence the hydrological cycle in forest ecosystems. In Hydroecology and Ecohydrology: Past, Present and Future; Wood, P., Hannah, D., Sadler, J., Eds.; John Wiley \& Sons, Ltd.: Hoboken, NJ, USA, 2008; pp. 7-35.

19. Veblen, T.; Donoso, C.; Kitzberger, T.; Rebertus, A. Ecology of southern chilean and argentinean nothofagus forests. In The Ecology and Biogeography of Nothofagus Forests; Veblen, T., Hill, R., Read, J., Eds.; Yale University Press: New Haven, CT, USA, 1996; pp. 293-353.

20. Armesto, J.J.; Smith-Ramírez, C.; Carmona, M.R.; Celis-Diez, J.L.; Díaz, I.A.; Gaxiola, A.; Gutiérrez, A.G.; Núnez-Avila, M.C.; Pérez, C.A.; Rozzi, R. Old-growth temperate rainforests of south america: Conservation, plant-animal interactions, and baseline biogeochemical processes. In Old-Growth Forests, Ecological Studies (Analysis and Synthesis); Wirth, C., Gleixner, G., Heimann, M., Eds.; Springer: Berlin, Germany, 2009; pp. 367-390.

21. Villagrán, C.; Hinojosa, L.F. Historia de los bosques del sur de sudamérica, ii: Análisis fitogeográfico. Revista Chilena de Historia Natural 1997, 70, 1-267.

22. Armesto, J.J.; Rozzi, R.; Smith-Ramirez, C.; Arroyo, M. Conservation Targets in South American Temperate Forests; American Association for the Advancement of Science: Washington, DC, USA, 1998.

23. Dentener, F. Global Maps of Atmospheric Nitrogen Deposition, 1860, 1993, and 2050. Available online: http:/ / daac.ornl.gov / (accessed on 12 November 2017).

24. Getis, A.; Ord, J.K. The analysis of spatial association by use of distance statistics. Geogr. Anal. 1992, 24, 189-206. [CrossRef]

25. Crain, B.J.; Tremblay, R.L. Do richness and rarity hotspots really matter for orchid conservation in light of anticipated habitat loss? Divers. Distrib. 2014, 20, 652-662. [CrossRef]

26. Kareiva, P.; Marvier, M. Conserving biodiversity coldspots: Recent calls to direct conservation funding to the world's biodiversity hotspots may be bad investment advice. Am. Sci. 2003, 91, 344-351. [CrossRef]

27. Kohlmann, B.; Roderus, D.; Elle, O.; Solís, Á.; Soto, X.; Russo, R. Biodiversity conservation in Costa Rica: A correspondence analysis between identified biodiversity hotspots (araceae, arecaceae, bromeliaceae, and scarabaeinae) and conservation priority life zones. Rev. Mex. Biodivers. 2010, 81, 511-559.

28. Fick, S.E.; Hijmans, R.J. Worldclim 2: New 1-km spatial resolution climate surfaces for global land areas. Int. J. Climatol. 2017, 37, 4302-4315. [CrossRef]

29. Jarvis, A.; Reuter, H.I.; Nelson, A.; Guevara, E. Hole-Filled Srtm for the Globe Version 4 Available From the CGIAR-CSI SRTM 90m Database. Available online: http:/ / srtm.csi.cgiar.org (accessed on 4 October 2017).

30. CONAF. Catastro de Uso de Suelo y Vegetación. Available online: http://www.ide.cl/descarga/capas / item/ catastros-de-uso-de-suelo-y-vegetacion.html (accessed on 2 October 2017).

31. IGN. Cobertura del Suelo. Available online: http://www.ign.gob.ar/NuestrasActividades/ InformacionGeoespacial/CapasSIG (accessed on 2 October 2017).

32. INE. Censo 2017. Available online: http://www.censo2017.cl/descargue-aqui-resultados-de-comunas / (accessed on 1 April 2018).

33. CONAF. Catastro de los Recursos Vegetacionales Nativos de Chile. Monitoreo de Cambios y Actualizaciones. Periodo 1997-2011; Ministerio de Agricultura: Santiago, Chile, 2011. 
34. CONAF; CONAMA; BIRF; Universidad Austral de Chile; Pontificia Universidad Católica de Chile; Universidad Católica de Temuco. Proyecto Catastro y Evaluación de los Recursos Vegetacionales Nativos de Chile; Ministerio de Agricultura: Santiago, Chile, 1999.

35. ESRI. Arc Hydro Tools Overview; ESRI Water Resources Team, Environmental Systems Research Institute: Redlands, CA, USA, 2011.

36. Ministerio de Obras Públicas (MOP). Balance Hídrico de Chile; Dirección General de Aguas: Santiago, Chile, 1987.

37. Ministerio de Bienes Nacionales (BBNN). Bienes Nacionales Protegidos. Available online: http://www.ide. cl/descarga/capas/item/bienes-nacionales-protegidos.html (accessed on 2 October 2017).

38. SIB. Sistema de Información de Biodiversidad y Administración de Parques Nacionales. Available online: https://mapas.parquesnacionales.gob.ar/layers/geonode\%3Aapn_areasprotegidas_01 (accessed on 15 February 2018).

39. Holz, A.; Veblen, T.T. Wildfire activity in rainforests in western patagonia linked to the southern annular mode. Int. J. Wildland Fire 2012, 21, 114-126. [CrossRef]

40. Arroyo, M. Los bosques de lenga de chile $i$ qué debemos hacer para asegurar su adecuada preservación y uso sustentable. In La Tragedia del Bosque Chileno; del Bosque Chileno, D., Ed.; Ocho Libros Editores: Santiago, Chile, 1998; pp. 110-116.

41. Bizama, G.; Torrejón, F.; Aguayo, M.; Muñoz, M.D.; Echeverría, C.; Urrutia, R. Pérdida y fragmentación del bosque nativo en la cuenca del río aysén (patagonia-chile) durante el siglo xx. Revista de Geografía Norte Grande 2011, 125-138. [CrossRef]

42. Myers, N. Biodiversity hotspots revisited. BioScience 2003, 53, 916-917.

43. Reyers, B.; O’Farrell, P.J.; Cowling, R.M.; Egoh, B.N.; Le Maitre, D.C.; Vlok, J.H. Ecosystem services, land-cover change, and stakeholders: Finding a sustainable foothold for a semiarid biodiversity hotspot. Ecol. Soc. 2009, 1, 38. [CrossRef]

44. Harris, N.L.; Goldman, E.; Gabris, C.; Nordling, J.; Minnemeyer, S.; Ansari, S.; Lippmann, M.; Bennett, L.; Raad, M.; Hansen, M. Using spatial statistics to identify emerging hot spots of forest loss. Environ. Res. Lett. 2017, 12, 024012. [CrossRef]

45. Di Minin, E.; Hunter, L.T.; Balme, G.A.; Smith, R.J.; Goodman, P.S.; Slotow, R. Creating larger and better connected protected areas enhances the persistence of big game species in the maputaland-pondoland-albany biodiversity hotspot. PLoS ONE 2013, 8, e71788. [CrossRef] [PubMed]

46. Li, Y.; Zhang, L.; Yan, J.; Wang, P.; Hu, N.; Cheng, W.; Fu, B. Mapping the hotspots and coldspots of ecosystem services in conservation priority setting. J. Geogr. Sci. 2017, 27, 681-696. [CrossRef]

47. Mac-Clure, R. La Sobrevivencia de Chile, la Conservación de sus Recursos Renovables, 2nd ed.; Ministerio de Agricultura: Santiago, Chile, 1970.

48. Gallo, G.S. Las economías silenciosas del litoral aisenino. In Tres Miradas antrOpológicas a la Región de Aysén; Mauricio, O., Gonzalo, S.G., Héctor, V.M., Eds.; Nirre Negro: Coyhaique, Chile, 2007.

49. Astorga, E. Istmo de Ofqui: Un Proceso Inconcluso de la Conectividad en la Región de Aysén; Nirre Negro: Coyhaique, Chile, 2016.

50. Gutiérrez, A.G.; Armesto, J.J.; Aravena, J.-C.; Carmona, M.; Carrasco, N.V.; Christie, D.A.; Peña, M.-P.; Pérez, C.; Huth, A. Structural and environmental characterization of old-growth temperate rainforests of northern chiloe island, chile: Regional and global relevance. For. Ecol. Manag. 2009, 258, 376-388. [CrossRef]

51. Bryant, D.; Nielsen, D.; Tangley, L. The Last Frontier Forests-Ecosystems Economies on the Edge; World Resources Institute (WRI): Washington, DC, USA, 1997.

52. Richter, B.D.; Baumgartner, J.V.; Powell, J.; Braun, D.P. A method for assessing hydrologic alteration within ecosystems. Conserv. Biol. 1996, 10, 1163-1174. [CrossRef]

53. Dörner, J.; Dec, D.; Peng, X.; Horn, R. Change of shrinkage behavior of an andisol in southern chile: Effects of land use and wetting/drying cycles. Soil Tillage Res. 2009, 106, 45-53. [CrossRef]

54. Anderson, C.B.; Pastur, G.; Lencinas, M.V.; Wallem, P.K.; Moorman, M.C.; Rosemond, A.D. Do introduced north american beavers castor canadensis engineer differently in southern south america? An overview with implications for restoration. Mammal Rev. 2009, 39, 33-52. [CrossRef]

55. Luebert, F.; Pliscoff, P. Sinopsis Bioclimática y Vegetacional de Chile; Editorial Universitaria: Santiago, Chile, 2006.

56. Peredo-Parada, M.; Martinez-Capel, F.; Quevedo, D.I.; Hernandez-Mascarell, A.B. Implementation of an eco-hydrological classification in chilean rivers/implementación de una clasificación eco-hidrológica para los ríos de chile. Gayana 2011, 75, 26-38. [CrossRef] 
57. Universidad de Chile. Clasificación de Cuerpos de Aguas, Reporte Final; Comisión Nacional de Medioambiente: Santiago, Chile, 2010.

58. Urciuolo, A.; Iturraspe, R.; Lofiego, R.; Noir, G. Estrategias para el ordenamiento hidro-ambiental de la cuenca binacional del río grande de tierra del fuego. In Proceedings of the XXII Congreso Nacional del Agua, Trelew, Argentina, 11-14 November 2009.

59. Abell, R.; Thieme, M.L.; Revenga, C.; Bryer, M.; Kottelat, M.; Bogutskaya, N.; Coad, B.; Mandrak, N.; Balderas, S.C.; Bussing, W. Freshwater ecoregions of the world: A new map of biogeographic units for freshwater biodiversity conservation. BioScience 2008, 58, 403-414. [CrossRef]

60. Millenium Ecosystems Assessment. Ecosystems and Human Well-Being: Synthesis; Island Press: Washington, DC, USA, 2005.

61. Donoso, P.J.; Frêne, C.; Flores, M.; Moorman, M.C.; Oyarzún, C.E.; Zavaleta, J.C. Balancing water supply and old-growth forest conservation in the lowlands of south-central chile through adaptive co-management. Landsc. Ecol. 2014, 29, 245-260. [CrossRef]

62. Reeves, G.H.; Williams, J.E.; Burnett, K.M.; Gallo, K. The aquatic conservation strategy of the northwest forest plan. Conserv. Biol. 2006, 20, 319-329. [CrossRef] [PubMed]

63. Lowe, W.H.; Likens, G.E.; Power, M.E. Linking scales in stream ecology. BioScience 2006, 56, 591-597. [CrossRef]

64. Lowrance, R.; Altier, L.S.; Newbold, J.D.; Schnabel, R.R.; Groffman, P.M.; Denver, J.M.; Correll, D.L.; Gilliam, J.W.; Robinson, J.L.; Brinsfield, R.B. Water quality functions of riparian forest buffers in chesapeake bay watersheds. Environ. Manag. 1997, 21, 687-712. [CrossRef]

65. Martyniuk, N.; Modenutti, B.; Balseiro, E. Forest structure affects the stoichiometry of periphyton primary producers in mountain streams of northern patagonia. Ecosystems 2016, 19, 1225-1239. [CrossRef]

66. Peterson, E.E.; Sheldon, F.; Darnell, R.; Bunn, S.E.; Harch, B.D. A comparison of spatially explicit landscape representation methods and their relationship to stream condition. Fresh. Biol. 2011, 56, 590-610. [CrossRef]

67. Gribovszki, Z.; Szilágyi, J.; Kalicz, P. Diurnal fluctuations in shallow groundwater levels and streamflow rates and their interpretation-A review. J. Hydrol. 2010, 385, 371-383. [CrossRef]

68. Nimick, D.A.; Gammons, C.H.; Parker, S.R. Diel biogeochemical processes and their effect on the aqueous chemistry of streams: A review. Chem. Geol. 2011, 283, 3-17. [CrossRef]

69. Contador, T.; Kennedy, J.H.; Rozzi, R.; Villarroel, J.O. Sharp altitudinal gradients in magellanic sub-antarctic streams: Patterns along a fluvial system in the cape horn biosphere reserve (55 s). Pol. Biol. 2015, 38, 1853-1866. [CrossRef]

70. Fisher, S.G.; Gray, L.J.; Grimm, N.B.; Busch, D.E. Temporal succession in a desert stream ecosystem following flash flooding. Ecol. Monogr. 1982, 52, 93-110. [CrossRef] 